Citation: M.C. Cavallini, S. Caravita (2021) Parental strategies for limiting youths' exposure to online risks. Media Education 12(2): 59-71. doi: 10.36253/ me-10474

Received: February, 2021

Accepted: September, 2021

Published: December, 2021

Copyright: $@ 2021$ Author. This is anopen access, peer-reviewed article published by Firenze University Press (http:// www.fupress.com/me) and distributed under the terms of the Creative Commons Attribution License, which permits unrestricted use, distribution, and reproduction in any medium, provided the original author and source are credited.

Data Availability Statement: All relevant data are within the paper and its Supporting Information files.

Competing Interests: The Author(s) declare(s) no conflict of interest.

\section{Parental strategies for limiting youths' exposure to online risks}

\author{
Strategie genitoriali per limitare l'esposizione dei giovani ai \\ rischi online
}

\author{
Maria Clara Cavallini ${ }^{1}$, Simona Caravita ${ }^{1,2}$ \\ ${ }^{1}$ Dipartimento di Psicologia, Università Cattolica del Sacro Cuore, Sede di Milano \\ ${ }^{2}$ Norwegian Center for Learning Environment and Behavioural Education \\ mariaclara.cavallini@unicatt.it; simona.c.caravita@uis.no
}

\begin{abstract}
Given the new risks and opportunities generated by the use of the Internet since childhood, it seems necessary to deepen the parental mediation strategies with which parents can protect their children from exposure to online risks, perpetration of inappropriate behaviours online and psychosocial risks associated with a dysfunctional use of the web. This scoping review aims to analyse the literature of the last ten years on the strategies and attitudes of parents towards online risks. Twenty-nine scientific documents about parental mediation outcomes on children's use of digital tools have been examined. Literature has been investigated in the PubMed, PsycINFO and Scopus databases. Only studies with a paediatric population published in the last ten years (from 2009) have been selected. The results suggest that empathy and interest are protective factors towards the exposure and perpetration of online risks of children, without limiting the opportunities offered by the Web.
\end{abstract}

Keywords: risks in ICT use, parental strategies, parental mediation, youth, maladjustment.

Riassunto. Considerati i nuovi rischi e le nuove opportunità generate dall'uso di Internet fin dall'infanzia, è necessario approfondire le strategie di mediazione con cui i genitori possono proteggere i loro figli dallesposizione ai rischi online, dalla perpetrazione di comportamenti inappropriati online e dai rischi psicosociali associati a un uso disfunzionale del Web. Questa scoping review mira ad analizzare la letteratura scientifica degli ultimi dieci anni riguardo le strategie e gli atteggiamenti dei genitori nei confronti dei rischi online. Sono stati esaminati ventinove documenti scientifici sulle diverse strategie di mediazione. La letteratura è stata indagata nei database PubMed, PsycINFO e Scopus. Sono stati selezionati solo gli studi con una popolazione pediatrica pubblicati negli ultimi dieci anni (dal 2009). I risultati suggeriscono che l'empatia e l'interesse dei genitori nei confronti del mondo online sono fattori protettivi nei confronti dell'esposizione e della perpetrazione dei rischi online dei bambini, senza limitare le opportunità offerte dal Web.

Parole chiave: Rischi nell'uso delle ICT, strategie dei genitori, mediazione genitoriale, giovani, disadattamento. 


\section{INTRODUCTION}

The fast spread of use of Information Communication Technology (ICT) by youths has increased the likelihood of their exposure to online risks. Research on parental mediation of children's Internet use is now beginning to consider the effectiveness of parental strategies in protecting children from exposure and perpetration of online risky behaviours. Nevertheless, we still need to identify the most effective ones.

This study aims to analyze the literature of the last ten years on the issue of parental mediation of the use of the Internet and ICTs. The purpose of this review is to understand whether and how mediation strategies and communication between parents and their children can decrease youth's exposure to ICT risks and their perpetration of online without limiting their opportunities to learn from the Web. Through this synthesis, mediation strategies can be suggested to parents, leading to a safer way for children to use new technologies. As recommended by evidence-based practices, the Prisma checklist (Preferred Reporting Items for Systematic reviews and Meta-Analyses) was used.

\subsection{Online risks}

Today's world presents some unique and new risks for the sexuality, intimacy and aggressiveness of youth (Machimbarrena et al., 2018). Children, in fact, more and more precociously, become part of a system in which communication is mediated by digital and ICT tools. Data from a Spanish study, for example, show that children start using mobile phones on average at the age of 7 years (Del Rio et al., 2019). In developing countries, such as Mexico, a survey has found that, although not all young people have their own computer or mobile phone, $100 \%$ of respondents between 12 and 16 years declared to use the Internet (Gutiérrez et al., 2013).

Smartphones and tablets offer children the opportunity to communicate with parents, socialize with friends, learn, develop creativity and have fun (Goggin \& Hjorth, 2014). Research has also shown that the use of social media in adolescence can be helpful for the development of social skills, empathy (Vossen \& Valkenburg, 2016) and problem-solving abilities (Adachi \& Willoughby, 2013). Furthermore, access to the Internet has been increasingly conceived as a basic tool for children's rights, because children's relationship with the world today is developed, to a large extent, through the network (Third et al., 2014). In fact, many of the dimensions of child well-being contained in the Universal Declaration of the Rights of the Child (1959) can be associated with the availability or lack of access to the Internet: it allows children to search for the information they may need, helps them reach free education and to have life models even far from those they experience daily, getting hopes and equal opportunities for their development.

A threat of the digital age, however, is represented by a possible problematic use of technological devices, especially related to the parents' inability to control the time spent on the net, the activities and contents that can be encountered online and that can have repercussions on children's social life or self-esteem (Spada, 2014).

There are three main categories of online risks: contact, content and conduct risks (Livingstone, 2019). The risks of contact include being lured or subjected to bullying, harassment or stalking. Content risks include visiting websites or inappropriate images that incite hatred, suicide, violence or thinness (García et al., 2014). Finally, conduct risks include the perpetration of cyber-bullying or harassment, the creation and the online uploading of pornographic material, gambling, illegal downloads, or providing advice on dangerous topics such as anorexia or suicide.

In a recent study, Kowalski et al. (2018) emphasize that among the most common consequences of cyberbullying there are problems in terms of emotional and behavioural regulation, substance use and reduction in self-esteem. Even sexting, i.e., voluntarily sending photos or videos of sexual content, is a relatively common behaviour among adolescents. A study in south-eastern Texas found that, among 964 adolescents $27.6 \%$ of the sample sent their own sex photos (Temple et al., 2012). For some adolescents, sexting can be a normal part of their development and sexual experimentation (Barrense-Dias et al., 2017). This behaviour, however, remains an important public health problem because it involves a risk for the reputation and it has been found to be associated with other risky behaviours such as the use of drugs, risky sexual behaviour and cyberbullying (Rice et al., 2014).

Improper use of the new forms of communication can also affect children's health, making them more sedentary and more likely to go to bed late, skip meals, eat in front of the computer (Gür et al.,2015), and sometimes it can lead to problems of psychological maladjustment and dependence (Horner et al., 2015).

\subsection{Parents in the digital world}

Social learning theory states that parental behaviour can influence and shape attitudes and thoughts of children (Bandura, 1977). This also occurs with regard to new media. Parents who watch, comment, and/or control children's use of the Internet and ICTs express 
explicit or implicit messages of approval or disapproval that remain relevant for children's risk assessment.

The main parenting techniques used to limit web risks are: restrictive mediation, active mediation and covision (Valkenburg et al.,1999).

Restrictive mediation occurs when parents impose rules that limit the time spent on the media (TV, videogames or the Internet) or the content that the child can access (ibid).

Active (or evaluative) mediation occurs when parents discuss with their children the risks of the web or other central issues related to the use of Internet and social networks, ICTs and media behaviours, such as the choices of a character or the consequences of an impulsive action, with the intent to promote their critical thinking (Glatz et al.,2018).

Finally, co-vision (or co-use) consists of using the media together with the child and includes two subgroups: intentional co-viewing, when parents assist children during browsing, and passive co-viewing, when parents are in the same room while their child or teenager uses the media (Chakroff \& Nathanson, 2008).

Parental involvement through awareness (Bass, 2016) and protection practices (Anderson, 2016) can be a protective factor against the various risks associated with the ICTs use. In the case of cyberbullying, for example, parental involvement in preventive programs can be beneficial for children both in terms of stopping the phenomenon and in terms of emotional support (Fridh et al., 2015; Özdemir 2014).

It is not yet clear, however, to what extent, and on what age group and gender, the different parental mediation strategies are effective in promoting a safe use of ICTs by young people. An in-depth analysis of the existing literature can be the starting point to provide correct information on this topic and develop interventions for children and parents.

\section{THE CURRENT STUDY}

Studies on parental mediation practices and their effectiveness are now many and different. This review collects and organizes them by bringing answers on effectiveness of parental mediation strategies in buffering the risks related to youth's use of ICTs based on scientific data. The selected studies all have parental mediation practices and their effect on children and adolescents as their central theme.

Main objective of the review was understanding which parental strategies are effective in limiting youth's exposure to risks connected to the use of media and
ICTs. In connection with this objective, we also examined the risk factors related to family or child that were identified by studies as affecting youth's exposure to online risks, because identifying these risk factors is preliminary to understanding the effectiveness of parental mediation strategies.

As a secondary goal of the review, we investigated which concerns about youth's use of ICTs are the most present among parents, because addressing the aspects of this use that are seen by adults as most harmful can be relevant for interventions with parents.

According to these objectives, in this review (a) first we identified the risk factors (e.g. age, gender, discrimination, disabilities) concerning parents and/or children with respect to online risk testing; (b) then we examined the main parental concerns with respect to online risks, according to results of the scientific literature; (c) lastly we investigated which types of parental strategies are the most effective for the protection of children and adolescents by ICTs risks according to the scientific literature.

Prisma checklist was used. Of all the studies (listed in the table 1) some characteristics are reported: country, the examined mediation strategies and risks and results concerning the mediation strategies.

\subsection{Method}

In order to individuate and select the relevant literature on this topic, we examined scientific texts indexed in three of the main important scientific databases: PubMed, PsychINFO and Scopus. We proceeded by using the key words "risky online behaviour", "social network" and "internet" and "parental mediation" and "parental supervision" contained in the title or abstract of the studies. Only articles and reviews produced in the Western context were selected to prevent environmental variables from affecting the results. Considering the fast developments of ICT technologies, only articles published in the last ten years have been selected (from 2009). This research has been accompanied by a manual search, conducted through Google Scholar. The google scholar search was conducted by matching the same terms "internet", "social network" and "online risky behaviour" with the terms "parental mediation" or "parental supervision" on the search engine. Of the articles found, only 7 fit the criteria and were deemed suitable for this study.

\subsection{Inclusion criteria}

Articles and reviews included met the following criteria: 
They evaluated parental mediation strategies for the protection of minors from online risks;

They included teenagers or parents of adolescents under the age of 18 ;

They have been produced in Western contexts (EU-US);

They have been published in peer-reviewed periodical;

They have been produced in the last 10 years (since 2009);

They are English-written;

They are Full text available.

\section{RESULTS}

According to the inclusion criteria, twenty-nine documents were selected (see Table 1): twenty-four articles and five reviews. Thirteen of the identified documents took into account both the parents' and children's point of view, twelve others considered only the point of view of the children, one also considered the opinions of the teachers, while three considered only parents' point of view.

The age range of the population whose use of the internet was studied was between 4 and 20 years although most of the analysed studies focused on the 10 -18 age group.

Of the 29 identified documents, 18 were produced in Europe, 7 in the United States, 2 considered data from Europe and the United States and 2 considered data from Europe, United States and Asia.

3.1. Gender and age differences as risk factor for youth's exposure to online risks

From a descriptive point of view, we first examined whether the literature identified youth's gender and age as moderators of the exposure to the online risks and of the use of mediation strategies by their parents. Many of the examined documents examined the differences in education and risky activities between males and females. A study conducted in Greece (Athanasiades et al., 2016) showed that males are more often perpetrators of cyberbullying. Even a recent study conducted in Italy (Baldry et al., 2019) found the same result. Furthermore, in Baldry and colleagues' study (ibid), in comparison to females, males reported to be less educated to correct use of social media, whereas females reported to be victims of cyber-bullying more often than males. Females were also more controlled by parents in their online activities. Although parents are less likely to help and support male than female children, results of the study by Vanderhoven and colleagues (2016) suggests that the impact of shared online activities with parents has a greater protective effect for males than females with regard to the dissemination of personal information.

The use of video games seems to be the only area in which males receive more temporal limitations than females (Gentile et al., 2012). However, parents are more likely to prevent their daughters than their sons from having specific violent video games available. Symons and colleagues (2017) carried out a study in which they used the distinction made by Livingstone and Haddon (2008) between contact and content risks. These authors, found that boys are more involved in content risks, spending more time on pornographic or violent sites, whereas girls are more likely to suffer from online harassment, which falls into contact risks. Parents also tend to believe that online interactions are potentially riskier for girls than boys, considering girls more vulnerable to online exploitation (Wright, 2017). Such beliefs could increase the likelihood that parents will implement mediation strategies with their daughters more often than with their sons.

\subsection{Diagnosed difficulties as risk factor for youth's exposure to online risks}

Some studies have taken into consideration individual variables that, regardless of parental mediation, can make children more or less predisposed to commit risky behaviours or suffer online harassment, identifying diagnosed difficulties as a possible risk factor.

Athanasiades and colleagues (2016) have conducted research on Greek adolescents (12 to 14 years), discovering how to be involved in traditional bullying and victimization and to use social networks for a longer time are the main risk factors for both perpetrating or suffering cyber-bullying. Wright's study (2017) also suggests that traditional bullying and peer pressure are risk factors for involvement in cyber aggression.

Del Rio and colleagues (2019) analysed data from minors that were part of the sample used in the Spanish Project of Net Children Go Mobile (Livingstone, 2019). Among this half thousand children, the authors detected a group of 61 minors with various diagnosed difficulties: learning problems (32), behavioural problems (6), disabilities (3), physical illness (3), mental disorders (6) or any other difficulties (11). They discovered that these vulnerable minors visited suicide and self-harm websites with a higher frequency than peers who did not report the same issues, respectively $22.7 \%$ against $7.8 \%$, and $25 \%$ against $15.5 \%$. The same study also showed that, unexpectedly, the frequency of parental mediation towards these children was lower than the 
Table 1. Description of studies used in scoping review $(\mathrm{N}=29)$.

\begin{tabular}{|c|c|c|c|c|}
\hline Authors & Country & Participants & Considered behaviours & Results on parental mediation \\
\hline $\begin{array}{l}\text { Álvarez, M., Torres, A., } \\
\text { Rodríguez, E., Padilla, S., \& } \\
\text { Rodrigo, M. J. (2013). }\end{array}$ & ES & $\begin{array}{l}771 \text { parents of } \\
\text { children }(10-14)\end{array}$ & Time online & $\begin{array}{l}\text { Restrictive mediation is associated with excessive } \\
\text { internet use by the child and his perception of loss } \\
\text { of control }\end{array}$ \\
\hline $\begin{array}{l}\text { Álvarez-García, D., García, } \\
\text { T., \& Suárez-García, Z. } \\
\text { (2017). }\end{array}$ & ES & $\begin{array}{l}946 \text { adolescents }(12- \\
18)\end{array}$ & Cyber-aggression & $\begin{array}{l}\text { Parental influence is limited. Slight negative } \\
\text { correlation between supervision and high-risk } \\
\text { behaviour }\end{array}$ \\
\hline $\begin{array}{l}\text { Álvarez-García, D., Núñez, } \\
\text { J. C., González-Castro, P., } \\
\text { Rodríguez, C., \& Cerezo, R. } \\
\text { (2019). }\end{array}$ & ES & $\begin{array}{l}3360 \text { adolescents } \\
(11-18)\end{array}$ & $\begin{array}{l}\text { Grooming, dissemination } \\
\text { of personal information, } \\
\text { sexting, cyber } \\
\text { victimization }\end{array}$ & $\begin{array}{l}\text { Restriction and supervision reduce high-risk and } \\
\text { cyber victimization }\end{array}$ \\
\hline $\begin{array}{l}\text { Athanasiades, C., Baldry, A. } \\
\text { C., Kamariotis, T., Kostouli, } \\
\text { M., \& Psalti, A. (2016). }\end{array}$ & GR & $\begin{array}{l}440 \text { adolescents }(12- \\
14)\end{array}$ & $\begin{array}{l}\text { Cyberbullying and cyber } \\
\text { victimization }\end{array}$ & Parental mediation is not protective \\
\hline $\begin{array}{l}\text { Baldry, A. C., Sorrentino, A., } \\
\text { \& Farrington, D. P. (2019). }\end{array}$ & IT & $\begin{array}{l}4390 \text { adolescents } \\
(13-20)\end{array}$ & $\begin{array}{l}\text { Cyberbullying and cyber } \\
\text { victimization }\end{array}$ & $\begin{array}{l}\text { Poor control over online activities by parents is } \\
\text { predictive of cyberbullying }\end{array}$ \\
\hline $\begin{array}{l}\text { Barlett, C. P., \& Fennel, M. } \\
(2018) \text {. }\end{array}$ & US & $\begin{array}{l}\text { Study } 1: 75 \text { parent- } \\
\text { adolescent dyads } \\
\text { (10-14). Study 2: } \\
165 \text { adolescents } \\
\text { (11-19). Study 3: } 96 \\
\text { adolescents (14-18) }\end{array}$ & Cyberbullying & $\begin{array}{l}\text { Poor parenting awareness of online activities is } \\
\text { predictive of cyberbullying }\end{array}$ \\
\hline $\begin{array}{l}\text { Bartau-Rojas, I., Aierbe- } \\
\text { Barandiaran, A., \& Oregui- } \\
\text { González, E. (2018). }\end{array}$ & ES & $\begin{array}{l}44 \text { ( } 37 \text { mothers and } \\
7 \text { fathers), third-year } \\
\text { students ( } 8-9 \text { years) } \\
\text { and sixth ( } 12-13 \\
\text { years) }\end{array}$ & $\begin{array}{l}\text { Social, psychological, } \\
\text { academic and physical } \\
\text { risks }\end{array}$ & Parents' digital competences are protective \\
\hline $\begin{array}{l}\text { Bleakley, Ellithorpe \& } \\
\text { Romer (2016). }\end{array}$ & US & $\begin{array}{l}629 \text { adolescents }(12- \\
17) \text { and one of their } \\
\text { parents }\end{array}$ & $\begin{array}{l}\text { Problematic Internet Use } \\
\text { (PIU) }\end{array}$ & $\begin{array}{l}\text { PIU is associated with less parental monitoring } \\
\text { and parental mediation and poorer parental } \\
\text { relationships. }\end{array}$ \\
\hline $\begin{array}{l}\text { Bosman, J., Bayraktar, F., \& } \\
\text { d'Haenens, L. (2015). }\end{array}$ & EU & $\begin{array}{l}25,142 \text { parent- } \\
\text { adolescent dyads } \\
(9-16)\end{array}$ & $\begin{array}{l}\text { Cyberbullying, cyber } \\
\text { victimization, addiction, } \\
\text { sexting, grooming }\end{array}$ & $\begin{array}{l}\text { Children discriminated against experience more } \\
\text { online risks. } \\
\text { Both the total lack of support and attention and } \\
\text { excessive limits can increase the experimentation of } \\
\text { online risks. }\end{array}$ \\
\hline $\begin{array}{l}\text { Byrne, S., Katz, S. J., Lee, } \\
\text { T., Linz, D., \& McIlrath, M. } \\
\text { (2014). }\end{array}$ & US & $\begin{array}{l}454 \text { parent-adolescent } \\
\text { dyads (10-16). } 94 \% \\
\text { moms }\end{array}$ & $\begin{array}{l}\text { Cyberbullying, grooming, } \\
\text { content risks }\end{array}$ & $\begin{array}{l}\text { Permissive parenting style, communication } \\
\text { difficulties and perceiving one's child as more } \\
\text { skilled than others are related to an underestimation } \\
\text { of online risks. Positive communication plays a } \\
\text { fundamental role in the child's level of openness }\end{array}$ \\
\hline $\begin{array}{l}\text { Collier, K. M., Coyne, S. M., } \\
\text { Rasmussen, E. E., Hawkins, } \\
\text { A. J., Padilla-Walker, L. M., } \\
\text { Erickson, S. E., \& Memmott- } \\
\text { Elison, M. K. (2016). }\end{array}$ & US & $\begin{array}{l}\text { Children and parents } \\
\text { in } 57 \text { studies }\end{array}$ & $\begin{array}{l}\text { Dependence, aggression, } \\
\text { substance use, sexual } \\
\text { behaviour }\end{array}$ & $\begin{array}{l}\text { Restrictive mediation is associated with less time } \\
\text { spent on social media. Active mediation reduces } \\
\text { aggressive or sexual behaviour and the likelihood } \\
\text { that they wish to use substances. Co-use is } \\
\text { associated with more aggressive behaviour and time } \\
\text { spent online }\end{array}$ \\
\hline $\begin{array}{l}\text { Del Río, M. C., Larrañaga, } \\
\text { M. G., \& Garnacho, C. G. } \\
(2019) \text {. }\end{array}$ & ES & $\begin{array}{l}61 \text { children/ } \\
\text { adolescents }(9-16) \\
\text { and one of their } \\
\text { parents }\end{array}$ & Content and contact risk & $\begin{array}{l}\text { Vulnerable children visit websites with inappropriate } \\
\text { content more often, which promote personal injury } \\
\text { or suicide or concern eating disorders. They receive } \\
\text { less restrictions on the use of the internet }\end{array}$ \\
\hline $\begin{array}{l}\text { Elsaesser, C., Russell, B., } \\
\text { Ohannessian, C. M., \& } \\
\text { Patton, D. (2017). }\end{array}$ & EU-US & $\begin{array}{l}\text { Parents and children } \\
(10-18) \text { in } 23 \text { studies }\end{array}$ & $\begin{array}{l}\text { Cyberbullying and cyber } \\
\text { victimization }\end{array}$ & $\begin{array}{l}\text { Empathy is a protective factor for cyberbullying, } \\
\text { perpetrated and suffered. Evaluative mediation } \\
\text { is more effective than restrictive mediation. The } \\
\text { authoritarian parenting style is correlated with the } \\
\text { perpetration of cyberbullying }\end{array}$ \\
\hline
\end{tabular}




\begin{tabular}{|c|c|c|c|c|}
\hline Authors & Country & Participants & Considered behaviours & Results on parental mediation \\
\hline $\begin{array}{l}\text { Fardouly, J., Magson, N. R., } \\
\text { Johnco, C. J., Oar, E. L., \& } \\
\text { Rapee, R. M. (2018). }\end{array}$ & $\mathrm{AU}$ & 284 preteens $(10-12)$ & $\begin{array}{l}\text { Time spent on social } \\
\text { media, comparisons, body } \\
\text { satisfaction }\end{array}$ & $\begin{array}{l}\text { More control over time spent on social media is } \\
\text { related to less time spent on social media and less } \\
\text { comparisons with others }\end{array}$ \\
\hline $\begin{array}{l}\text { Gentile, D. A., Nathanson, } \\
\text { A. I., Rasmussen, E. E., } \\
\text { Reimer, R. A., \& Walsh, D. } \\
\text { A. (2012). }\end{array}$ & US & $\begin{array}{l}1,323 \text { children }(9-11) \text {, } \\
\text { their parents and } \\
\text { teachers. }\end{array}$ & $\begin{array}{l}\text { Dependence, exposure to } \\
\text { violent content, lowering } \\
\text { school performance }\end{array}$ & $\begin{array}{l}\text { Time limits have a direct effect on academic } \\
\text { performance }\end{array}$ \\
\hline $\begin{array}{l}\text { Gómez, P., Harris, S. K., } \\
\text { Barreiro, C., Isorna, M., \& } \\
\text { Rial, A. (2017). }\end{array}$ & ES & $\begin{array}{l}39.993 \text { adolescents } \\
(12-17)\end{array}$ & $\begin{array}{l}\text { Internet addiction, } \\
\text { isolation }\end{array}$ & $\begin{array}{l}\text { Gambling and bullying, being threatened or } \\
\text { blackmailed are reported more frequently by those } \\
\text { who report that they are not controlled by their } \\
\text { parents }\end{array}$ \\
\hline $\begin{array}{l}\text { Hutson, E., Kelly, S., \& } \\
\text { Militello, L. K. (2018). }\end{array}$ & $\begin{array}{l}\text { EU-US- } \\
\text { AS }\end{array}$ & $\begin{array}{l}\text { Parents and children } \\
(10-20) \text { in } 23 \text { studies }\end{array}$ & $\begin{array}{l}\text { Cyberbullying and cyber } \\
\text { victimization }\end{array}$ & $\begin{array}{l}\text { The prevention programs that involved parents were } \\
\text { among the most functional }\end{array}$ \\
\hline $\begin{array}{l}\text { Kalmus, V., Blinka, L., \& } \\
\text { Olafsson, K. (2015). }\end{array}$ & EU & $\begin{array}{l}1000 \text { children/ } \\
\text { adolescents }(9-16) \\
\text { and one of their } \\
\text { parents }\end{array}$ & $\begin{array}{l}\text { Excessive Internet Use } \\
\text { (EIU) }\end{array}$ & $\begin{array}{l}\text { Direct rules limiting the child's use of particular } \\
\text { applications or activities are associated with lower EIU. } \\
\text { Technical solutions were not strongly correlated with a } \\
\text { lower EIU score. Active parental mediation of Internet } \\
\text { use prevents children's exposure to online risks }\end{array}$ \\
\hline Kirwil, L. (2009). & EU & $\begin{array}{l}1,949 \text { parents/ } \\
\text { guardians of children } \\
(6-17)\end{array}$ & Online & $\begin{array}{l}\text { Only social co-use seems related to fewer online } \\
\text { risks experienced by children }\end{array}$ \\
\hline $\begin{array}{l}\text { Livingstone, S., Ólafsson, } \\
\text { K., Helsper, E. J., Lupiáñnez- } \\
\text { Villanueva, F., Veltri, G. A., } \\
\text { \& Folkvord, F. (2017). }\end{array}$ & EU & $\begin{array}{l}6400 \text { parents of } \\
\text { children }(6-14)\end{array}$ & $\begin{array}{l}\text { Dissemination of personal } \\
\text { information }\end{array}$ & $\begin{array}{l}\text { A more restrictive mediation has been associated } \\
\text { with fewer risks but also fewer opportunities }\end{array}$ \\
\hline $\begin{array}{l}\text { Normand, C. L., \& } \\
\text { Sallafranque-St-Louis, F. } \\
(2016) \text {. }\end{array}$ & EU-US & $\begin{array}{l}\text { Adolescents }(9-17) \text { in } \\
57 \text { studies }\end{array}$ & $\begin{array}{l}\text { Cyberbullying, cyber } \\
\text { victimization, sexting }\end{array}$ & $\begin{array}{l}\text { High parent-child conflict places } 5 \text { times more at } \\
\text { risk of making risky use of Internet victimization, } \\
\text { harassment, lack of sexual knowledge, difficulty } \\
\text { in expressing consent and greater likelihood of } \\
\text { depression and isolation }\end{array}$ \\
\hline $\begin{array}{l}\text { Rodríguez-de-Dios, I., van } \\
\text { Oosten, J. M., \& Igartua, J. } \\
\text { J. (2018). }\end{array}$ & ES & 1446 students (12-18) & Opportunities and risks & $\begin{array}{l}\text { Restrictive mediation reduces the risks but also the } \\
\text { digital abilities of the children }\end{array}$ \\
\hline $\begin{array}{l}\text { Schneider, L. A., King, D. L., } \\
\text { \& Delfabbro, P. H. (2017). }\end{array}$ & AS - El & $\begin{array}{l}\text { Children (4-18) in } 14 \\
\text { studies }\end{array}$ & $\begin{array}{l}\text { Problem use of video } \\
\text { games }\end{array}$ & $\begin{array}{l}\text { A poorer parent-child relationship is associated with } \\
\text { increased gambling problems }\end{array}$ \\
\hline $\begin{array}{l}\text { Symons, K., Ponnet, K., } \\
\text { Emmery, K., Walrave, M., \& } \\
\text { Heirman, W. (2017). }\end{array}$ & $\mathrm{BE}$ & $\begin{array}{l}357 \text { triads (mother, } \\
\text { father, adolescent } \\
13-18 \text { ) }\end{array}$ & $\begin{array}{l}\text { Cybervittimization, } \\
\text { cyberbullying, solicitation, } \\
\text { exposure to violent or } \\
\text { pornographic content }\end{array}$ & $\begin{array}{l}\text { Monitoring practices were linked to mothers } \\
\text { and fathers' self-perceived knowledge about their } \\
\text { children's online activities. } \\
\text { Parents' knowledge of the risks experienced by their } \\
\text { children is very low }\end{array}$ \\
\hline $\begin{array}{l}\text { Symons, K., Vanwesenbeeck, } \\
\text { I., Walrave, M., Van Ouytsel, } \\
\text { J., \& Ponnet, K. (2019). }\end{array}$ & $\mathrm{BE}$ & $\begin{array}{l}357 \text { valid triads } \\
\text { (fathers, mothers and } \\
\text { adolescents 13-18) }\end{array}$ & $\begin{array}{l}\text { Contact with strangers on } \\
\text { SNS, SNS frequency }\end{array}$ & $\begin{array}{l}\text { Maternal and paternal internet mediation } \\
\text { contributes to the child's safe online behaviour }\end{array}$ \\
\hline $\begin{array}{l}\text { Van Den Eijnden, R. J., } \\
\text { Spijkerman, R., Vermulst, A. } \\
\text { A., van Rooij, T. J., \& Engels, } \\
\text { R. C. (2010). }\end{array}$ & NL & $\begin{array}{l}4,483 \text { Dutch students } \\
+510 \text { Dutch } \\
\text { adolescents }(10-16)\end{array}$ & $\begin{array}{l}\text { CIU (compulsive Internet } \\
\text { Use) }\end{array}$ & $\begin{array}{l}\text { Good communication regarding the Internet } \\
\text { prevents teenagers from developing CIU. Strict rules } \\
\text { about time of internet use may promote compulsive } \\
\text { tendencies }\end{array}$ \\
\hline $\begin{array}{l}\text { Vanderhoven, E., Schellens, } \\
\text { T., \& Valcke (2016). }\end{array}$ & $\mathrm{BE}$ & $\begin{array}{l}207 \text { adolescents } \\
\text { (average age 12.6) }\end{array}$ & $\begin{array}{l}\text { Dissemination of personal } \\
\text { information }\end{array}$ & $\begin{array}{l}\text { Parental involvement changed the intentions to } \\
\text { engage in certain unsafe behaviours, such as the } \\
\text { publication of personal and sexual information }\end{array}$ \\
\hline $\begin{array}{l}\text { Wisniewski, P., Jia, H., Xu, } \\
\text { H., Rosson, M. B., \& Carroll, } \\
\text { J. M. (2015). }\end{array}$ & US & $\begin{array}{l}588 \text { teens (ages } 12- \\
\text { 17) and one of their } \\
\text { parents }\end{array}$ & Information disclosure & $\begin{array}{l}\text { Direct intervention reduces teen exposure to online } \\
\text { risks but also their ability to engage with others } \\
\text { online and to learn how to cope with online risks }\end{array}$ \\
\hline Wright, M. F. (2017). & US & $\begin{array}{l}568 \text { adolescents } \\
\text { (average age 13.4) }\end{array}$ & $\begin{array}{l}\text { Cyberbullying, cyber } \\
\text { victimization }\end{array}$ & $\begin{array}{l}\text { Restrictive mediation protects against cyberbullying } \\
\text { but not from victimization. Co-vision is negatively } \\
\text { related to all forms of cyber aggression. Active } \\
\text { mediation protects against victimization but not } \\
\text { from perpetration }\end{array}$ \\
\hline
\end{tabular}


mediation carried out by parents with typically developing children.

Normand \& Sallafranque-St-Louis (2017) in their review found that risk factors associated with higher rates of cyberbullying, online victimization and time spent online were physical or intellectual disabilities, depressive symptoms and being victim of traditional bullying. Even the study by Bosman and colleagues (2015) suggests that children with problems on a physical or intellectual level, and perceived as "discriminated against" by their parents, experience more online risks (sexting, encountering unknown contacts, and cybervictimization) than their peers.

In particular, children in the group perceived as discriminated showed slightly more adventurous or risky online behaviour; they more often looked for new friends online, sent personal information to strangers, added more unknown people to the list of friends and also pretended more often to be a different person. They also had more offline meetings with known contacts on the net than peers, but this difference ( $34 \%$ compared to $36 \%$ of non-discriminated children) was not significant. Surprisingly, the discriminated children $(20 \%)$ reported to feel bothered by one or more of these meetings more frequently than non-discriminated children (12\%).

3.3. Communication and empathy with parents as risk factor for youth's exposure to online risks

Several studies (Bleakley et al., 2016; Bosman et al., 2015; Byrne, et al., 2014; Elsaesser et al., 2017; Kalmus et al., 2015; Normand \& Sallafranque - St - Louis, 2016; Schneider et al., 2017; Van Den Eijnden et al. 2010) examined the family context, in particular the relationship between parents and children. Results from this research agree that positive parent-child communication and high levels of perceived empathy by children represent protective factors against risky online activities.

Specifically, Normand \& Sallafranque St-Louis (2016) found that high levels of parent-child conflict are associated with a five times higher risk of testing sexual risks online. Youths who feel alone, isolated or misunderstood, perceive a lack of support from their families and fall into a subgroup particularly prone to a risky use of the ICTs. In particular, they are more likely (i) to suffer sexual and physical abuse and victimization experiences in general; (ii) to have poor sexual knowledge (iii); to have difficulty in expressing consent and recognizing abusive situations; (iv) to suffer depression; (v) to have the perception of being rejected and less opportunity to have romantic or sexual partners; and (vi) to search for the company of strangers online and offline when they are alone. Elsaesser and colleagues (2017), in their literature review of 23 studies about preventing cyberbullying, found that, in comparison to their parents, adolescents report more communication problems and lower levels of family satisfaction and family cohesion, and this perceived poor family empathy, combined with excessive restrictions that are carried out by parents, can increase the risk of gambling and cyberbullying.

Finally, Schneider et al., (2017) showed how a poorer parent-child relationship is associated with an increase in online gambling problems. Problematic gamblers reported to spend less time in social activities with their parents, and to live in a family environment worse than the one reported by players who did not have dependency issues.

\subsection{Parents' concerns regarding online risks}

Parents mention both positive and negative functions of using ICTs for their children, however the percentage of the negative aspects they mention (70\%) is more than double, when compared to the percentage of the reported positive aspects (30\%) (Bartau-Rojas et al., 2018).

Main parents' concern $(30 \%)$ is that children can have access to inappropriate content (violent, pornographic, stereotyped or drug), without having sufficient maturity and knowledge to recognize them (ibidem). A study by Padilla-Walker and colleagues (2012) identifies another strong concern from parents: the excessive amount of time spent by youth online. That is, parents fear that, when adequate restrictions and control are absent, visiting online websites could take up too much youth's time from other activities or from being together in the family.

Other concerns are related to the youth's socialization. According to parents and teachers, face-to-face contact between young people has been reduced over time since the increase in diffusion of ICT technologies, because communicating with friends online is physically easier than going out and playing with them (Gentile et al., 2012). Parental concerns also relate to possible addiction to the use of ICT technologies, a consequent lack of social skills, loss of imagination and the academic consequences (Bartau-Rojas et al.,2018). Risks related to the privacy or the sexual sphere, and to the lack of real and positive models were also mentioned. There are also fears related to possible academic and learning difficulties, such as increased frequency of misspellings in young people and possible decrease of attention levels (ibidem). Finally, with regards to physical health and abilities, parents fear that, in comparison to the past, 
youth's physical conditions can be worse, due to a more sedentary life and the reduction of time spent outdoors or sport activities (ibid). Nevertheless, the main worries of parents pertain to the uncertainty about the activities and contents which their children are exposed to, possible children's exposure to actions of other online users, and their own difficulties in controlling the actions acted by their children online (ibid). On the positive side, however, in the same study by Bartau-Rojas et al. (2018) parents also mentioned several opportunities that the Internet use offers to children, starting from early childhood. In particular, parents highlighted how the use of the Internet can favour users' integration, autonomy and critical attitudes with respect to what is read or seen. Parents also expressed satisfaction with regards to possible increase in children's ability in finding places and in spatial orientation due to the use of smartphones.

\subsection{Active and restrictive parental mediation: Which type is the most effective?}

The study by Bartau-Rojas and colleagues (2018) indicates how, in general, parental mediation on youth's use of Internet and ICTs tends to be more negative than positive, as parents state more rules and prohibitions on what children "do not" have to do online than providing indications about what children "could do" in order to benefit from the use of media. Parental mediation also tends to be more reactive than proactive, resulting more frequently as a consequence of an unpleasant event than a strategy that is planned in advance. Several of the studies we identified (Âlvarez-García et al., 2018; Baldry et al., 2019; Barlett \& Fennel, 2018; Bartau-Rojas et al., 2018; Elsaesser et al., 2017; Gómez et al., 2017) show that either parents, in reality, are generally unaware of their children's online activities, or they are perceived as such by their children. Furthermore, parents often do not fully understand how applications and software that are used by youth work.

Studies also indicate that adolescents tend to know and implement strategies in order to circumvent parents' rules and prohibitions. For instance, adolescents avoid leaving traces of the activities they carried out on their devices, or they make parental control and dialogue with parents on ICT use more difficult (Álvarez-García et al., 2018).

The identified studies also highlight how much parents tend to overestimate the controls and the rules they impose, and their role as mediators as well, when answering about their mediation of children's use of technological tools (Barlett \& Fennel, 2018; Gentile et al., 2012). Barlett \& Fennel (2018) also found that the less parents were aware of their children's online activities, the more it was likely that children engaged in aggressive online behaviour. This finding suggests the importance of digital literacy for parents. The research by Byrne and colleagues (2014) also showed that, generally, parents underestimate the possibility that their children can commit risky activities online, for themselves or for others, especially when they consider their children socially more skilled than other children.

With regards to the effectiveness of parental mediations strategies, it should be pointed out that of the twenty-nine documents we analysed, only one (Athanasiades et al., 2016) found no beneficial or protective effects by parenting mediation on children's perpetration of high-risk online behaviours or being a victim of cyberbullying. Some studies have been specific about parental efforts to prevent online risks exposure, analysing the effects of different parental strategies on children's involvement in online risks. These studies found a significantly greater effect by the use of evaluative mediation than adopting only restrictive mediation strategies (Álvarez-García et al., 2017; Barlett, 2018; Bosman et al., 2015). Evaluative mediation of Internet use was also effective in reducing problematic offline behaviours, such as involvement in early sexual relationships or substance use (Collier et al., 2016). The results coming from using restrictive mediation are more controversial. Although some research has found beneficial effects by adopting this type of strategies (Collier et al., 2016; Gentile et al., 2012; Livingstone et al., 2017), there are studies that highlight a positive association between parents' use of restrictive mediation and higher rates of youth's online risky behaviours (Elsaesser et al., 2017), and being cyberbullied (Baldry et al., 2019). It may be hypothesized that parental restrictions are more likely when parents suspect that their children are engaging in risky behaviour or are suffering harassment on the Web (Baldry et al., 2019). Parental restrictive mediation strategies, also, have been found to be related to benefitting from less opportunities on the Internet for the youth (Livingstone et al., 2017; Wisniewski et al., 2015). Furthermore, two European studies (Kalmus, 2015; Rodríguez-de-Dios et al.,) showed that posing limitations and restrictions reduce children's exposure to risks, but this is a predictive factor for children's developing poor digital skills. Nevertheless, in a study involving 284 early adolescents (10-12 years), Fardouly and colleagues (2018) showed that limiting children's online time had a positive effect on mental health. In particular, parental control over the time preadolescents spend on social media was associated with fewer appearance comparisons with others on social media, which in turn was associated with better pre ado- 
lescent mental health. These results, however, could be specific for the early adolescence age of the sample (1012 ) on which the study is based.

Collier et al. (2016), on the other hand, in a metaanalysis conducted in the United States on 57 studies, found positive correlations between parents' adoption of restrictive strategies and children's aggressive behaviour and time spent online. Moreover, one study (Livingstone et al., 2017) shows that parents who consider themselves digitally more skilled tend to implement active or evaluative mediation to a higher extent than parents who do not believe they have sufficient digital knowledge, as the latter ones only try to apply greater limitations and restrictions to their children's online activities.

In three studies (Kirwii, 2009; Vanderhoven et al., 2016; Wright, 2017), the co-vision strategy has been found to lead to significant benefits. Two of these studies showed how this strategy decreases cyberbullying and the exposure to risks for privacy, and it reduces perpetrating unsafe behaviour in social network activities (Vanderhoven et al., 2016; Wright, 2017). In a study based on data from 1949 parents Kirwii (2009) found that only social co-use (sitting next to the child when they are online) is related to fewer online risks experienced by children.

Based on the studies we analysed, we can conclude that the active or "evaluative" mediation seems to be the most effective strategy of mediation, as the results concerning this type of mediation tend to be less controversial than the results on restrictive mediation. Active mediation, in fact, seems to lead to a lower exposure to online risks by youth, without negatively influencing youth's digital skills and their opportunities in the virtual world.

\section{CONCLUSION}

Main purpose of this review of studies was to bring greater awareness and concrete responses to psychologists and families on the effectiveness of parental mediation of digital tools in buffering youth's exposure to online risks. Specifically, the goals were (a) identifying the risk factors concerning family and/or children with respect to exposure to online risks, (b) understanding main parental concerns with respect to online risks, (c) assessing which types of parental strategies are the most effective for the protection of children and adolescents from online risks.

As regards to the risk factors of improper use of the web, this review identified both individual characteristics of adolescents and variables related to the family context. Among the individual characteristics that make a minor more predisposed to a more dysfunctional use of the web there are having suffered traditional bullying and having some difficulties in the areas of learning and physical and mental health (Athanasiades et al., 2016; Del Rio et al., 2019).

However, studies that evaluate the family context seem to agree that an open parent-child communication and youth's perception of a good relationship with parents are associated with lower youth's exposure to online risks (Bleakley et al., 2016; Bosman et al., 2015; Byrne et al., 2014; Elsaesseret al., 2017; Kalmus et al.,2015; Normand \& Sallafranque - St - Louis, 2016; Schneider et al., 2017).

Parents also seem to identify more negative than positive aspects of ICT use. One of parents' major concerns is the types of content that their children could access on a daily basis and that could have a negative impact especially at an early age (Bartau-Rojas et al., 2018)

The results on parental mediation strategies indicate that active mediation is the strategy most frequently associated with lower levels of exposure to online risks for children and adolescents. Using active mediation, parents can discuss appropriate and realistic attitudes and behaviours in using ICT tools, thus helping youth to develop a more critical view about the online world. These results can be attributed to the fact that, despite restricting significant time and content, protecting children from inappropriate or aggressive messages shared through the ICT technologies is difficult. Parents can use active mediation techniques to contextualize such messages, supporting the development of critical thinking by their children. There is also evidence that active discussions about media are also associated with prevention of substance use (Collier et al., 2016).

Knowing more about children's online activities seems to be a very important aspect of practicing mediation strategies, as well as parents' good digital skills: Adolescents will talk less about the problems they experience online if they think that their parents are digitally incompetent (Baldry et al., 2019). Moreover, youth will be less likely to argue with adults if the latter ones only tend to interrupt their activities and connections. It is more likely that young people try to hide their online activities when parents use this type of mediation, thus unintentionally increasing the risk of cyber-bullying and cyber victimization. Parental online monitoring must be able to protect children and the studies indicate that the effectiveness of this strategy is influenced by the fact that children perceive parents as competent and understand that they can be supported by parents, rather than 
limited, controlled or deprived of their own devices. This implies that parents, in order to be good mediators, should not apply excessive restrictions, as much as they should be aware of what is happening to their children, share concerns with them and provide digital knowledge. Moving the computer to a public place in the home can be a good technique, but it is difficult to apply, since the most parents control the use of the Internet, the most it is likely that young people will find a way to overcome parental rules, for example by using a friend's computer or mobile phone (Byrne \& Lee, 2011). Therefore, an open parent-child communication can be the most reasonable solution. Indeed, the inability to communicate increases the likelihood that parents underestimate whether their child has been contacted by a stranger or experience other risks in the online environment (Byrne et al., 2014).

Promoting interventions focused on communication between parents and children and aimed at knowing the real social skills of children can be an important preventive action (ibid).

Parents who are not yet digitally able or do not use social networks should be encouraged to familiarize themselves with the ICTs, so that they can be able to consciously guide their children in the best use of these tools.

Although the search terms included were wide-ranging ("internet," "parental mediation," and "social networking"), no studies that fit the criteria analysed ways in which parents could guide their children through the Web for positive purposes.

Only two studies (Livingstone et al., 2017; Wisniewski et al, 2015) in the entire review cited not only online risks, but also opportunities provided by the web.

Despite the challenges, the research shows that, for both males and females, parental mediation is an important factor to increase youth's opportunities stemming from the use of internet and digital communication tools.

The study by Fardouly et al. (2018) indicates that restrictive mediation strategy is useful in protect mental health in pre-adolescence, while other documents suggest the importance of active mediation rather than restrictive mediation (Álvarez-García et al., 2017; Barlett, 2018; Bosman et al., 2015).

Finally, it should be noticed that a growing percentage of young people with intellectual or developmental problems use ICTs and their number is likely to further increase due to the development of websites and ICT tools that are increasingly easy to use for populations with low levels of literacy (Del Rio et al., 2019). These young people are more vulnerable, especially with regard to sexual solicitation. Therefore, concentrating digital education efforts precisely on this type of users becomes increasingly important (Collier et al., 2016).

\section{LIMITATION AND FUTURE RESEARCH}

This review of the literature is not without limits: first, it is possible that not all the articles written on the topic have been identified.

Also, there are no specific conclusions related to which type of mediation strategy has to be used to prevent specific online risky behaviour (e.g., sexting, excessive use of internet, cyberbullying).

Furthermore, the literature on parents' role in adolescent ICTs use is mostly composed by correlational studies, making conclusions on causality difficult. There is a need for more studies on this topic, including intervention studies that target families.

Nevertheless, this review helped to identify some important elements on which to focus future interventions. First, it seems necessary to increase parents' awareness on technology and on its use by adolescents. Second, a positive communication between parents and children needs to be promoted, in order to reduce the disparity between what adolescents are doing online and what their parents think about, with positive repercussions on the online safety of young users. A third, relevant aspect highlighted by the literature review implemented in this study is how research aimed at assessing the effectiveness of parenting strategies in mediating in a positive rather than "protective" or "reactive" manner is absent. Future studies could investigate these aspects in order to understand how to transmit knowledge and skills related to the use of the Internet from parents to children.

Finally, the percentage of young people with intellectual or developmental disabilities using the Internet and ICTs is increasing, also due to the development of user-friendly sites for people with low literacy levels (Normand \& Sallafranque-St-Louis, 2016). When considering that these populations of users are particularly vulnerable, we need more research on the online risk protection of these youths.

\section{REFERENCES}

Adachi, P. J., \& Willoughby, T. (2013). More than just fun and games: The longitudinal relationships between strategic video games, self-reported problem-solving skills, and academic grades. Journal of youth and adolescence, 42(7), 1041-1052. https://doi.org/10.1007/ s10964-013-9913-9

Álvarez-García, D., García, T., \& Suárez-García, Z. (2018). The Relationship between parental control and high-risk internet behaviours in adolescence. 
Social Sciences, 7(6), 87. https://doi.org/10.3390/socsci7060087

Anderson, P. (2012). Web 2.0 and beyond: Principles and technologies. CRC Press. https://doi.org/10.5210/ fm.v0i0.4227

Athanasiades, C., Baldry, A. C., Kamariotis, T., Kostouli, M., \& Psalti, A. (2016). The "net" of the internet: Risk factors for cyberbullying among secondary-school students in Greece. European Journal on Criminal Policy and Research, 22(2), 301-317. https://doi. org/10.1007/s10610-016-9303-4

Baldry, A. C., Sorrentino, A., \& Farrington, D. P. (2019). Post-traumatic stress symptoms among Italian preadolescents involved in school and cyber bullying and victimization. Journal of Child and Family Studies, 28(9), 2358-2364. https://doi.org/10.1007/s10826018-1122-4

Bandura, A., \& Walters, R. H. (1977). Social learning theory (Vol. 1). Englewood Cliffs, NJ: Prentice-hall. http://www.asecib.ase.ro/mps/Bandura_SocialLearningTheory.pdf

Barlett, C. P., \& Fennel, M. (2018). Examining the relation between parental ignorance and youths' cyberbullying perpetration. Psychology of Popular Media Culture, 7(4), 547. https://doi.org/10.1037/ ppm0000139

Barrense-Dias, Y., Berchtold, A., Surís, J. C., \& Akre, C. (2017). Sexting and the definition issue. Journal of Adolescent Health, 61(5), 544-554. https://doi. org10.1016j.jadohealth.2017.05.009

Bartau-Rojas, I., Aierbe-Barandiaran, A., \& OreguiGonzález, E. (2018). Mediación parental del uso de Internet en el alumnado de Primaria: creencias, estrategias y dificultades. Comunicar, 26(54), 71-79. https://doi.org/10.3916/C54-2018-07

Bass III, P. F. (2016). Living life online: Talking to parents about social media. Contemporary paediatrics, 33(5), 21-25. https://www.contemporarypediatrics.com/ node/10885\%3Fpage\%3D0\%252C3

Bleakley, A., Ellithorpe, M., \& Romer, D. (2016). The role of parents in problematic internet use among US adolescents. Media and Communication, 4(3), 24-34. http://dx.doi.org/10.17645/mac.v4i3.523

Bosman, J., Bayraktar, F., \& D'Haenens, L. (2015). Children's digital media practices within the European family home: Does perceived discrimination matter? Journal of Children and Media, 9(1), 77-94. https:// doi.org/10.1080/17482798.2015.997099

Byrne, S., \& Lee, T. (2011). Toward predicting youth resistance to internet risk prevention strategies. Journal of Broadcasting \& Electronic Media, 55(1), 90-113. https://doi.org/10.1080/08838151.2011.546255
Byrne, S., Katz, S. J., Lee, T., Linz, D., \& McIlrath, M. (2014). Peers, predators, and porn: Predicting parental underestimation of children's risky online experiences. Journal of Computer-Mediated Communication, 19(2), 215-231. https://doi.org/10.1111/jcc4.12040

Chakroff, J. L., \& Nathanson, A. I. (2008). Parent and school interventions: Mediation and media literacy. The handbook of children, media, and development, 552-576. https://doi.org/10.1002/9781444302752.ch24

Del Río, M. C., Larrañaga, M. G., \& Garnacho, C. G. (2019). Internet and Spanish children with learning and behavioural problems and other disabilities. Revista Latina de Comunicación Social, 74, 653-667. http:// www.revistalatinacs.org/074paper/1350/33en.html

Elsaesser, C., Russell, B., Ohannessian, C. M., \& Patton, D. (2017). Parenting in a digital age: A review of parents' role in preventing adolescent cyberbullying. Aggression and violent behavior, 35, 62-72. http:// dx.doi.org/10.1016/j.avb.2017.06.004

Fardouly, J., Magson, N. R., Johnco, C. J., Oar, E. L., \& Rapee, R. M. (2018). Parental control of the time preadolescents spend on social media: Links with preadolescents' social media appearance comparisons and mental health. Journal of youth and adolescence, 47(7), 1456-1468. https://doi.org/10.1007/s10964-018-0870-1

Fridh, M., Lindström, M., \& Rosvall, M. (2015). Subjective health complaints in adolescent victims of cyber harassment: moderation through support from parents/friends-a Swedish population-based study. BMC public health, 15(1), 949. https://doi.org/10.1186/ s12889-015-2239-7

García, B. C., de Ayala López, M. L., \& Jiménez, A. G. (2014). Los riesgos de los adolescentes en Internet: los menores como actores y víctimas de los peligros de Internet. Revista latina de comunicación social, 69, 462-485. http://www.revistalatinacs.org/069/ paper/1020_UR/23es.html

Gentile, D. A., Nathanson, A. I., Rasmussen, E. E., Reimer, R. A., \& Walsh, D. A. (2012). Do you see what I see? Parent and child reports of parental monitoring of media. Family Relations, 61(3), 470-487. https://doi.org/10.1111/j.17413729.2012.00709.x

Glatz, T., Crowe, E., \& Buchanan, C. M. (2018). Internetspecific parental self-efficacy: developmental differences and links to Internet-specific mediation. Computers in human behavior, 84, 8-17. https://doi. org/10.1016/j.chb.2018.02.014

Goggin, G., \& Hjorth, L. (Eds.). (2014). The Routledge companion to mobile media. Routledge. http://jasonfarman.com/JasonFarman_Storytelling-with-MobileMedia.pdf 
Gómez, P., Harris, S. K., Barreiro, C., Isorna, M., \& Rial, A. (2017). Profiles of Internet use and parental involvement, and rates of online risks and problematic Internet use among Spanish adolescents. Computers in Human Behavior, 75, 826-833. https://doi. org/10.1016/j.chb.2017.06.027

Gutiérrez, R., Vega, L., \& Rendón, A. E. (2013). Usos de la Internet y teléfono celular asociados a situaciones de riesgo de explotación sexual de adolescentes. Salud mental, 36(1), 41-48. https://doi. org/10.17711/SM.0185-3325.2013.006

Gür, K., Yurt, S., Bulduk, S., \& Atagöz, S. (2015). Internet addiction and physical and psychosocial behavior problems among rural secondary school students. Nursing \& health sciences, 17(3), 331-338. https://doi. org/10.1111/nhs.12192

Heiman, T., \& Olenik-Shemesh, D. (2015). Cyberbullying experience and gender differences among adolescents in different educational settings. Journal of Learning Disabilities, 48(2), 146-155. https://doi. org/10.1177/0022219413492855

Horner, S., Asher, Y., \& Fireman, G. D. (2015). The impact and response to electronic bullying and traditional bullying among adolescents. Computers in human behavior, 49, 288-295. https://doi. org/10.1016/j.chb.2015.03.007

Kalmus, V., Blinka, L., \& Olafsson, K. (2015). Does it matter what mama says: Evaluating the role of parental mediation in European adolescents' excessive Internet use. Children \& Society, 29(2), 122-133. https://doi.org/10.1111/chso.12020

Kirwil, L. (2009). Parental mediation of children's internet use in different European countries. Journal of Children and Media, 3(4), 394-409. https://doi. org/10.1080/17482790903233440

Kowalski, R. M., Limber, S. P., \& McCord, A. (2019). A developmental approach to cyberbullying:

Prevalence and protective factors. Aggression and Violent Behavior, 45, 20-32. https://doi.org/10.1016/j. avb.2018.02.009

Livingstone, S. (2019). EU kids online. The international encyclopedia of media literacy, 1-17. https://doi. org/10.1002/9781118978238.ieml0065.

Livingstone, S., \& Haddon, L. (2008). Risky experiences for children online: Charting European research on children and the internet. Children \& society, 22(4), 314-323. https://doi.org/10.1111/j.10990860.2008.00157.x

Machimbarrena, J., Calvete, E., Fernández-González, L., Álvarez-Bardón, A., Álvarez-Fernández, L., \& González-Cabrera, J. (2018). Internet risks: An overview of victimization in cyberbullying, cyber dating abuse, sexting, online grooming and problematic internet use. International journal of environmental research and public health, 15(11), 2471. https://doi. org/10.3390/ijerph15112471

Normand, C. L., \& Sallafranque-St-Louis, F. (2016). Cybervictimization of young people with an intellectual or developmental disability: Risks specific to sexual solicitation. Journal of Applied Research in Intellectual Disabilities, 29(2), 99-110. https://doi.org/10.1111/jar.12163

Özdemir, Y. (2014). Cyber victimization and adolescent self-esteem: The role of communication with parents. Asian Journal of Social Psychology, 17(4), 255-263. https://doi.org/10.1111/ajsp.12070

Padilla-Walker, L. M., Coyne, S. M., Fraser, A. M., Dyer, W. J., \& Yorgason, J. B. (2012). Parents and adolescents growing up in the digital age: Latent growth curve analysis of proactive media monitoring. Journal of adolescence, 35(5), 1153-1165. https://doi. org/10.1016/j.adolescence.2012.03.005

Rice, E., Gibbs, J., Winetrobe, H., Rhoades, H., Plant, A., Montoya, J., \& Kordic, T. (2014). Sexting and sexual behavior among middle school students. Pediatrics, 134(1), e21-e28. https://doi.org/10.1542/peds.2013-2991

Rodríguez-de-Dios, I., van Oosten, J. M., \& Igartua, J. J. (2018). A study of the relationship between parental mediation and adolescents' digital skills, online risks and online opportunities. Computers in Human Behavior, 82, 186-198. https://doi.org/10.1016/j. chb.2018.01.012

Schneider, L. A., King, D. L., \& Delfabbro, P. H. (2017). Family factors in adolescent problematic Internet gaming: a systematic review. Journal of behavioral addictions, 6(3), 321-333. https://doi. org/10.1556/2006.6.2017.035

Spada, M. M. (2014). An overview of problematic Internet use. Addictive behaviors, 39(1), 3-6. https://doi. org/10.1016/j.addbeh.2013.09.007

Symons, K., Ponnet, K., Emmery, K., Walrave, M., \& Heirman, W. (2017). Parental knowledge of adolescents' online content and contact risks. Journal of youth and adolescence, 46(2), 401-416. http://hdl.handle.net/1854/LU-8514197

Temple, J. R., Paul, J. A., Van Den Berg, P., Le, V. D., McElhany, A., \& Temple, B. W. (2012). Teen sexting and its association with sexual behaviors. Archives of pediatrics \& adolescent medicine, 166(9), 828-833. https://doi.org/10.1001/archpediatrics.2012.835

Third, A., Bellerose, D., Dawkins, U., Keltie, E., \& Pihl, K. (2014). Children's rights in the digital age: A download from children around the world. http://www. uws.edu.au/_data/assets/pdf_file/0003/753447/Childrens-rights-in-the-digital-age.pdf 
Valkenburg, P. M., Krcmar, M., Peeters, A. L., \& Marseille, N. M. (1999). Developing a scale to assess three styles of television mediation: "Instructive mediation,"'restrictive mediation," and "social coviewing". Journal of broadcasting \& electronic media, 43(1), 52-66. https://doi.org/10.1080/08838159909364474

Van Den Eijnden, R. J., Spijkerman, R., Vermulst, A. A., van Rooij, T. J., \& Engels, R. C. (2010). (2010). Compulsive internet use among adolescents: bidirectional parentchild relationships. Journal of Abnormal Child Psychology, 38(1), 77-89. https://doi.org/10.1007/s10802-0099347-8

Vanderhoven, E., Schellens, T., Vanderlinde, R., \& Valcke, M. (2016). Developing educational materials about risks on social network sites: a design based research approach. Educational technology research and development, 64(3), 459-480. http://hdl.handle.net/1854/ LU-6985885

Vossen, H. G., \& Valkenburg, P. M. (2016). Do social media foster or curtail adolescents' empathy? A longitudinal study. Computers in Human Behavior, 63, 118-124. https://doi.org/10.1016/j.chb.2016.05.040

Wisniewski, P., Jia, H., Wang, N., Zheng, S., Xu, H., Rosson, M. B., \& Carroll, J. M. (2015). Resilience mitigates the negative effects of adolescent internet addiction and online risk exposure. Proceedings of the 33rd Annual ACM Conference on Human Factors in Computing Systems, Seoul, Korea. https://doi. org/10.1145/2702123.2702240

Wright, M. F. (2017). Parental mediation, cyberbullying, and cybertrolling: The role of gender. Computers in Human Behavior, 71, 189-195. https://doi. org/10.1016/j.chb.2017.01.059 